\section{Prevalence of thyroid disorders among older people: results from the São Paulo Ageing \& Health Study}

\author{
Prevalência de doenças da tireóide em idosos: \\ resultados do São Paulo Ageing \& Health Study
}

\author{
1 Hospital Universitário, \\ Universidade de São Paulo, \\ São Paulo, Brasil. \\ 2 Faculdade de Medicina, \\ Universidade de São Paulo, \\ São Paulo, Brasil. \\ Correspondence \\ A. C. Goulart \\ Hospital Universitário, \\ Universidade de São Paulo. \\ Av. Lineu Prestes 2565, São \\ Paulo, SP 05508-000, Brasil. \\ alecgoulart@yahoo.com.br
}

\begin{abstract}
This study aimed to estimate prevalence of thyroid disorders in the São Paulo Ageing \& Health Study, an epidemiological study addressing several health-adverse outcomes among elderly people living in a poor area of São Paulo, Brazil. All participants answered a questionnaire and had a blood sample collected to assess levels of tireotropic hormone and free-thyroxine. Among 1,373 people (60.8\% women), prevalence rates ( $95 \%$ confidence interval) for thyroid dysfunction (\%) were: overt hyperthyroidism, 0.7\% (0.2-1.1) [women: 0.8\% (0.2-1.5); men: 0.4\% (0.01-0.9)]; overt hypothyroidism, 5.7\% (4.5-6.9) [women: 5.9\% (4.3-7.5); men: 5.4\% (3.5-7.3)]; subclinical hyperthyroidism, 2.4\% (1.6-3.2) [women: $2.8 \%$ (1.6-3.9); men: 1.9\% (0.7-3.0)]; and subclinical hypothyroidism, 6.5\% (5.2-7.8) [women: 6.7\% (5.08.4); men: 6.1\% (4.1-8.2)]. There was no difference in prevalence rates according to gender, but almost $40 \%$ of women were diagnosed and under treatment compared to 9\% of men. The burden of thyroid disorders in this sample is high and most participants were not aware of them.
\end{abstract}

Thyroid Diseases; Aged; Hyperthyroidism; Hypothyroidism
Isabela M. Benseñor 1

Alessandra Carvalho Goulart 1

Paulo A. Lotufo 1

Paulo Rossi Menezes 2

Marcia Scazufca ${ }^{2}$

\section{Introduction}

Thyroid diseases are frequent in older individuals, and symptoms of hypothyroidism such as tiredness, fatigue, lack of concentration or dry skin can be very similar to complaints associated to ageing 1,2. Even for hyperthyroidism, clinical presentation in elderly people is much more silent when compared to middle-aged people 3 . Beyond symptoms associated with thyroid disorders, epidemiologic studies have shown a possible association between subclinical and overt thyroid disorders and cardiovascular disease $3,4,5,6$.

A review published by the American College of Physicians estimated for population studies a pooled prevalence of overt hypothyroidism in women $\geq 70$ years of $2 \%$ and in men $\geq 60$ years of $0.8 \%$. For overt hyperthyroidism, the numbers were $0.6 \%$ for women $\geq 60$ years and $0.1 \%$ for men $\geq 60$ years 7 . Based on these data, some authors 8,9 , have recommended screening for thyroid disorders especially in elderly people but this is not the view expressed in position papers from both the US Preventive Services Task Force 10 and the Canadian Task Force 11. However, among older people with unspecified complaints, to rule out thyroid dysfunction is always a dilemma considering that only one third of cases show typical signs and symptoms of the disease, and treatment is cost effective 12. 
The present study addresses the prevalence of thyroid disorders in a population-based sample of low-income elderly people living in São Paulo, Brazil.

\section{Methods}

A cross-sectional population-based study was carried out with residents of an economically deprived area of São Paulo. Participants were those enrolled in the baseline assessment of the São Paulo Ageing \& Health Study whose methodology can be assessed elsewhere 13,14 .

\section{Sample}

The baseline assessment of the São Paulo Ageing \& Health Study was carried out among all people aged 65 years or older who are residents in 66 pre-determined census sectors (catchment areas) in the area of Butantan, a neighborhood located on the Western side of São Paulo city. Study participants lived in shantytowns ("favelas"), or households covered by the Family Health Program, with the lowest family income in the area. A total of 2,072 persons (91.4\% of those invited) were recruited through systematic door knocking and were included in the São Paulo Ageing \& Health Study 1,15. As the investigation of thyroid disorders started after the baseline assessment of the São Paulo Ageing \& Health Study was underway, 699 (33.7\%) participants included in the São Paulo Ageing \& Health Study with no data about thyroid function were excluded from the present study. As such, 1,373 people had their blood sample collected to assess levels of thyroid stimulating hormone (TSH) and free-thyroxin (F-T4) and were included in the study. Anti-thyroperoxidase antibodies were evaluated in a random sub sample of 545 participants including men and women. There was no statistically significant difference between the alleatory subsample of elderly people submitted to anti-thyroperoxidase antibodies assessment compared to the others regarding proportion of women (respectively, 63.6 vs. $59.7, \mathrm{p}=0.34$ ), age [73 years $(6.6)$ vs. 71.9 (6.5), $\mathrm{p}=0.27$ ], body-mass index [25.5 kg/m² (4.4) vs. 26.2 (4.7), $\mathrm{p}=0.35$ ], age-strata $(\mathrm{p}=0.67)$, and school-years $(\mathrm{p}=0.14)$.

\section{Procedures}

The study was conducted over a two-year period, from May 2003 to April 2005. A group of interviewers trained to work in the present study carried out recruitment and interviewing of the participants. All those aged 65 years or over liv- ing in the study catchment area who accepted to participate in the study were interviewed. This meant that in households with two or more elderly people, all of them were invited to participate. All participants were assessed for socioeconomic characteristics.

A venous blood sample was obtained after an overnight fast. The serum obtained after centrifugation was used for hormone and biochemistry measurements. TSH concentration (reference range $0.45-4.5 \mathrm{mIU} / \mathrm{L}$ ) was measured by immunometric assay (kit AutoDelfiahTSH; Perkinelmer Wallac Inc., Waltham, USA) and F-T4 concentration (reference range 0.6-1.8ng/ $\mathrm{dL}$ ) was also determined using an immunometric assay (kit AutoDelfia T4; Perkinelmer Wallac Inc. Waltham Massachussets, USA). Anti-thyroid peroxidase (Tpoab) antibodies concentration (reference range $<35 \mathrm{IU} / \mathrm{mL}$ ) was measured by radioimmunoassay, using kit TpoAb RIA C.T. (BC 1018; Biocode SA, Liège, Belgium).

Thyroid dysfunction was assessed using TSH and F-T4 as well as routine use of thyroid hormones or antithyroid medications. There were no cases of hypothyroidism post thyroidectomy in this sample. Cut-off levels for TSH were < $0.4 \mathrm{IU} / \mathrm{dL}$ for hyperthyroidism and $>5.0 \mathrm{IU} / \mathrm{dL}$ for hypothyroidism. Cut-off levels for F-T4 were < $0.8 \mathrm{ng} / \mathrm{mL}$ for hypothyroidism and $>1.8$ for hyperthyroidism. People in the sample were classified in five categories for both hormones: clinical hyperthyroidism (low serum TSH combined with high levels of F-T4), subclinical hyperthyroidism (low serum TSH with normal levels of F-T4), euthyroidism (normal TSH and normal F-T4), subclinical hypothyroidism (high TSH with normal F-T4) and clinical hypothyroidism (high TSH combined with low levels of F-T4).

Age was classified in four strata: 65-69, 70-74, 75-79 and $\geq 80$ years old. Education was classified according to number of school-years in three categories: none, 1 to 3 , and $\geq 4$ years. Birth location was classified by country, state and city where each individual was born as well as the number of years they lived in areas of borderline iodine intake, the age each person arrived in São Paulo and how many years he/she has lived in the city of São Paulo since then. The interviewer evaluated the use of prescription and over-the-counter medicines at home. He/she also checked dosage and interval time of administration of regular medical treatments, including medicines for hyperthyroidism or hypothyroidism.

\section{Data analysis}

Data entry was carried out twice using the Epidata 3.0 program (Epidata Assoc., Odense, Den- 
mark), and the validity check was carried out to identify and correct data entry errors. Data was analyzed using SPSS 15.0 (SPSS Inc., Chicago, USA). Prevalence of thyroid disease rates are presented as the number of cases per 100 persons. Ninety-five percent confidence intervals were also presented for prevalence. Chi-square tests were used for comparison when appropriate. Chi-square for linear trend analysis was used to measure the age effects of thyroid disease prevalence. A p value less than 0.05 was considered statistically significant.

\section{Ethics}

The study was approved by the Institutional Review Board and all participants signed an informed consent form, according to the Declaration of Helsinki.

\section{Results}

Mean values of TSH were, for women and men respectively, 2.9 (5.4) $\mu \mathrm{IU} / \mathrm{mL}$ and 2.9 (5.3) $\mu \mathrm{IU} /$ $\mathrm{mL}$; median values were $1.8(1.1-2.9) \mu \mathrm{IU} / \mathrm{mL}$ in women and $1.8(1.1-3.0) \mu \mathrm{IU} / \mathrm{mL}$ in men. Minimum and maximum values were respectively 0.0 and $94.0 \mu \mathrm{IU} / \mathrm{mL}$ in women and 0.0 and $99.9 \mu \mathrm{IU} /$ $\mathrm{mL}$ in men. Mean values of F-T4 were respectively for women and men $1.0(0.2) \mathrm{ng} / \mathrm{dL}$ and $1.1(0.7)$ $\mathrm{ng} / \mathrm{dL}$; median values were of 1.8 (1.1-2.9) $\mathrm{ng} / \mathrm{dL}$ being exactly the same in women and men. Minimum and maximum values were $0.01 \mathrm{ng} / \mathrm{dL}$ and $2.6 \mathrm{ng} / \mathrm{dL}$ in women and $0.0 \mathrm{ng} / \mathrm{dL}$ and $99.9 \mathrm{ng} /$ dL in men.

Table 1 shows general characteristics of men and women in the sample according to thyroid function. No difference was found regarding these characteristics according to thyroid function. Table 2 shows prevalence of subclinical and clinical thyroid disease according to gender. We did not find any difference in the prevalence of clinical and subclinical thyroid diseases according to gender.

Table 3 shows the prevalence of thyroid disease by age range and gender. Frequency of thyroid disorders for both sexes did not change significantly according to age range, although the frequency of overt hyperthyroidism in men was too small to allow for any conclusions. The proportion of participants who grew up in an area of iodine deficiency was different between the genders: $80.8 \%$ of women and $85.3 \%$ of men raised in an area of low iodine intake during infanthood $(\mathrm{p}=0.04)$.

Of the seven women with overt hyperthyroidism, three $(42.9 \%)$ were under treatment. Of the two men in the same condition, one $(50 \%)$ was also under treatment. Of these four people, all have normal levels of TSH, suggesting good control. Of the 56 women with overt hypothyroidism, 21 (38.2\%) were under treatment. For the 33 men in the same condition, only three (9.1\%) were under treatment. Of all 24 hypothyroid people under treatment, all the men and 17 (81\%) of the women were under control; three (14.2\%) women were partially controlled (subclinical hypothyroidism) and one was out of control (high levels of TSH combined with low F-T4 levels). The difference in the prevalence of hypothyroidismin women compared to men was statistically significant ( $\mathrm{p}=0.006$ ) showing a high number of diagnoses in women compared to men.

Prevalence of anti-thyroperoxidase antibodies was of $10.7 \%$ in women and $9.2 \%$ in men with no difference between them $(\mathrm{p}=0.34)$. There was no difference in the prevalence of anti-thyroperoxidase antibodies according to age-strata for men, women or both together (data not showed).

\section{Discussion}

In this sample of older men and women, prevalence rates of overt hyperthyroidism were $0.8 \%$ in women and $0.4 \%$ in men; for hypothyroidism, prevalence was $5.9 \%$ in women and $5.4 \%$ in men. Regarding subclinical thyroid diseases, prevalence of subclinical hyperthyroidism was $2.8 \%$ in women and $1.9 \%$ in men; and for subclinical hypothyroidism, prevalence in women was $6.7 \%$ and in men was $6.1 \%$. There was no difference in the prevalence rates of thyroid diseases according to gender.

Regarding diagnosis and control, of all the women with overt thyroid disease, $38.7 \%$ had been diagnosed and were under control, corresponding to $42.8 \%$ of hyperthyroid women and $38.2 \%$ of hypothyroid women. For men with overt thyroid disease, $11.4 \%$ had been diagnosed and were under control, corresponding to $50 \%$ of hyperthyroid men, and only $9.1 \%$ of hypothyroid men. Data suggest that there is a gender bias in diagnosis of hypothyroidism in this sample of older men and women.

Comparing our data with similar data from other studies using the same cut-off, frequency of hypothyroidism in this sample is higher than the pooled prevalence of hypothyroidism in population-based studies of $2 \%$ in women aged 70 to 80 ; and of $1 \%$ in women and $0.7 \%$ in men aged over 607 . However, these data are similar to data results from the Colorado Thyroid Disease Prevalence Study in which $16 \%$ of women and 
Characteristics of participants according to thyroid status.

\begin{tabular}{|c|c|c|c|c|c|}
\hline Characteristics & $\begin{array}{l}\text { Overt } \\
\text { hyperthyroidism } \\
(n=9)\end{array}$ & $\begin{array}{l}\text { Subclinical } \\
\text { hyperthyroidism } \\
(n=33)\end{array}$ & $\begin{array}{c}\text { Normal } \\
\text { function } \\
(n=1,164)\end{array}$ & $\begin{array}{c}\text { Subclinical } \\
\text { hypothyroidism } \\
(\mathrm{n}=89)\end{array}$ & $\begin{array}{c}\text { Overt } \\
\text { hypothyroidism } \\
(\mathrm{n}=78)\end{array}$ \\
\hline Proportion of female (\%) & $7(77.8)$ & $23(69.7)$ & $700(60.1)$ & $56(62.9)$ & $49(62.8)$ \\
\hline $\begin{array}{l}\text { Mean age and standard } \\
\text { deviation [years] }\end{array}$ & $70.8(4.3)$ & $71.2(6.2)$ & $72.1(6.3)$ & $72.4(6.7)$ & $71.3(5.6)$ \\
\hline \multicolumn{6}{|l|}{ Age-strata [years] (\%) } \\
\hline $65-69$ & $4(0.7)$ & $16(2.7)$ & $503(84.3)$ & $38(6.4)$ & $36(6.0)$ \\
\hline $70-74$ & $3(0.8)$ & $9(2.4)$ & 319 (83.9) & $23(6.1)$ & $26(6.8)$ \\
\hline $75-79$ & $2(0.9)$ & $6(2.7)$ & $190(86.4)$ & $14(6.4)$ & $8(3.6)$ \\
\hline$\geq 80$ & $0(0,0)$ & $2(1.1)$ & $152(86.4)$ & $14(8.0)$ & $8(4.5)$ \\
\hline \multicolumn{6}{|l|}{ School-years (\%) } \\
\hline Illiterate & $2(0.4)$ & $10(1.8)$ & $471(85.2)$ & $41(7.4)$ & $29(5.2)$ \\
\hline $1-4$ & $7(1.0)$ & $21(3.0)$ & $582(83.7)$ & $40(5.8)$ & $45(6.5)$ \\
\hline$>4.0$ & $0(0.0)$ & $1(0.8)$ & 108 (89.3) & $8(6.6)$ & $4(3.3)$ \\
\hline Born/raised in goiter-area (\%) & $7(77.8)$ & $30(90.9)$ & $956(83.5)$ & $74(86.0)$ & $62(81.6)$ \\
\hline
\end{tabular}

Table 2

Prevalence (\%; and 95\% confidence interval) of thyroid dysfunctions in older people according to gender.

\begin{tabular}{|c|c|c|c|c|c|c|c|}
\hline \multirow[t]{2}{*}{ Thyroid dysfunctions } & \multicolumn{2}{|c|}{ All $(N=1,373)$} & \multicolumn{2}{|c|}{ Men $(n=538)$} & \multicolumn{2}{|c|}{ Women $(n=835)$} & \multirow[t]{2}{*}{ p-value } \\
\hline & $\mathbf{n}$ & $\%$ & $\mathbf{n}$ & $\%$ & $\mathbf{n}$ & $\%$ & \\
\hline Subclinical hyperthyroidism & 33 & $2.4(1.6-3.2)$ & 10 & $1.9(0.7-3.0)$ & 23 & $2.8(1.6-3.9)$ & 0.61 \\
\hline Overt hyperthyroidism & 9 & $0.7(0.2-1.1)$ & 2 & $0.4(0.01-0.9)$ & 7 & $0.8(0.2-1.5)$ & \\
\hline Subclinical hypothyroidism & 89 & $6.5(5.2-7.8)$ & 33 & $6.1(4.1-8.2)$ & 56 & $6.7(5.0-8.4)$ & \\
\hline Overt hypothyroidism & 78 & $5.7(4.5-6.9)$ & 29 & $5.4(3.5-7.3)$ & 49 & $5.9(4.3-7.5)$ & \\
\hline
\end{tabular}

$11 \%$ of men between 65 and 74 years old had a TSH higher than $5.0 \mathrm{IU} / \mathrm{L}$ compared to $12.6 \%$ of women and $11.5 \%$ of men in the present study 16 . Parle et al. 6 found a prevalence of hypothyroidism in a population-based sample of people over 60 of $8.3 \%$ considering both men and women compared to $5.7 \%$ in the present study. Recently, Gussekloo et al. 17 found a prevalence of subclinical hypothyroidism in $5.1 \%$ and of overt hypothyroidism in $1.2 \%$ in 588 individuals of both gender over the age of 85 . In comparison with the Colorado Prevalence Study, the frequency of thyroid disease is very similar for men and women in São Paulo 16 .

Regarding hyperthyroidism, a review of several previous studies gave a pooled prevalence of $0.7 \%$ in women over 607 . In a recent study by Gussekloo et al. 17 with a sample of men and women, prevalence of overt hyperthyroidism was $0.3 \%$ and of subclinical hyperthyroidism was $2.9 \%$, very similar to $2.4 \%$ for subclinical and $0.7 \%$ for overt disease in our sample.

Diagnosis of previous overt hypothyroidism in this sample was carried out with more frequency in women than in men $(\mathrm{p}=0.006)$. We can speculate that, first, women look for medical treatment more frequently than do men 16,17,18,19. Second, it is possible that there is some kind of gender bias. As thyroid disease is more frequent in women than in men, physicians screen thyroid function in elderly women more frequently compared to men 20,21 .

Frequency of thyroid disorders in this sample did not change according to age-strata. In the Colorado study, prevalence of an elevated TSH increased with age for men and women 16 . 
Prevalence of thyroid disease by gender according to age-strata.

\begin{tabular}{|c|c|c|c|c|c|}
\hline & \multicolumn{4}{|c|}{ Age-strata (years) } & \multirow[t]{2}{*}{ p-value } \\
\hline & $65-69$ & $70-74$ & 75-79 & $\geq 80$ & \\
\hline All [N =1,373 (100\%)] & $597(43.5)$ & $380(27.7)$ & $220(16.0)$ & $176(12.8)$ & 0.87 \\
\hline Subclinical hyperthyroidism & $16(2.7)$ & $9(2.4)$ & $6(2.7)$ & $2(1.1)$ & \\
\hline Overt hyperthyroidism & $4(0.7)$ & $3(0.8)$ & $2(0.9)$ & 0 & \\
\hline Subclinical hypothyroidism & $38(6.4)$ & $23(6.1)$ & $14(6,4)$ & $14(8,0)$ & \\
\hline Overt hypothyroidism & $36(6.0)$ & $26(6.8)$ & $8(3.6)$ & $8(4.5)$ & \\
\hline Men $[n=538(100 \%)]$ & 247 (45.9) & $147(27.3)$ & 80 (14.9) & 64 (11.9) & 0.43 \\
\hline Subclinical hyperthyroidism & $4(1.6)$ & $2(1.4)$ & $3(3.8)$ & $1(1.6)$ & \\
\hline Overt hyperthyroidism & $1(0.4)$ & - & $1(1.3)$ & - & \\
\hline Subclinical hypothyroidism & $14(5.7)$ & $9(6.1)$ & $7(8.8)$ & $3(4.7)$ & \\
\hline Overt hypothyroidism & $13(5.3)$ & $13(8.8)$ & $1(1.3)$ & $2(3.1)$ & \\
\hline Women [n = 835 (100\%)] & $350(41.9)$ & 233 (27.9) & $140(16.8)$ & $112(13.4)$ & 0.86 \\
\hline Subclinical hyperthyroidism & $12(3.4)$ & $7(3.0)$ & $3(2.1)$ & $1(0.9)$ & \\
\hline Overt hyperthyroidism & $3(0.9)$ & $3(1.3)$ & $1(0.7)$ & - & \\
\hline Subclinical hypothyroidism & $24(6.9)$ & $14(6.0)$ & $7(5.0)$ & $11(9.8)$ & \\
\hline Overt hypothyroidism & $23(6.6)$ & $13(5.6)$ & $7(5.0)$ & $6(5.4)$ & \\
\hline
\end{tabular}

Hollowell et al. 22 have also found similar results. However, data from Parle et al. 6, in 1,193 patients, showed a stable prevalence of elevated $\mathrm{TSH}$ concentration in men and women over the age of 60, as did Sawin et al. 1 using data from the Framingham Study. Andersen-Ranberg et al. 15, studying centenarians concluded that thyroid dysfunction did not seem more prevalent among centenarians than among young old people. Another possibility is that the results may have been subject to bias due to the small number of people over 70 in our sample, caused by a higher rate of cardiovascular disease mortality in a very low-income sample.

In this sample of ageing people, anti-thyroperoxidase antibodies were constant and did not change according to age. Data from the $\mathrm{Na}$ tional Health and Nutrition Examination Survey (NHANES III) showed a prevalence of antithyroperoxidase antibodies that increases with age in both men and women 22 . Again, the small number of people aged over 70 could be an explanation for this result.
Prevalence of thyroid disease in this sample is almost the same for men and women with a women/men ratio of 1.1 for overt hypothyroidism and of 1.2 for all thyroid disease. These data could be explained by the fact that more men than women in this sample were born and grew up in areas of low iodine intake $(80.3 \%$ in women vs. $85.3 \%$ in men, $\mathrm{p}=0.004$ ). Although we now have some data from other studies showing a more than adequate iodine uptake in Brazil especially after 1996, we did not evaluate iodine intake in our sample 1,22.

Concluding, our results showed a prevalence of thyroid disease in women similar to other countries. However, prevalence of thyroid disease in men is higher than results in other countries with a women/men ratio of 1.2 for all thyroid disease and for overt hypothyroidism, with most men with hypothyroidism in this sample being undiagnosed. 


\section{Resumo}

O objetivo da pesquisa foi avaliar a prevalência de doenças da tireóide no São Paulo Ageing \& Health Study, estudo epidemiológico focado em desfechos de saúde adversos em amostra de idosos moradores de São Paulo, Brasil. Todos os participantes responderam a questionário e colheram sangue para dosagem de hormônio tireotrópico e tiroxina-livre. Entre os 1.373 participantes (60,8\% mulheres), a prevalência (intervalo de $95 \%$ de confiança) de hipertireoidismo clínico foi de 0,7\% (0.2-1,1) [mulheres: 0,8\% (0,2-1,5); homens: 0,4\% (0,01-0,9)]; hipotireoidismo clínico, 5,7\% (4,56,9) [mulheres: 5,9\% (4,3-7,5); homens: 5,4\% (3,5-7,3)]; hipertireoidismo subclínico, 2,4\% (1,6-3,2) [mulheres: 2,8\% (1,6-3,9); homens: 1,9\% (0,7-3,0)]; e hipotireoidismo subclínico, 6,5\% (5,2-7,8) [mulheres: 6,7\% (5,08,4); homens: 6,1\% $(4,1-8,2)]$. Não houve diferença na prevalência de doenças da tireóide por sexo. Quarenta por cento das mulheres tinham diagnóstico e estavam tratando, comparadas a 9\% dos homens. A prevalência de disfunção tireoidiana foi elevada e a maioria dos participantes desconhecia o diagnóstico.

Doenças da Glândula Tireóide; Idoso; Hipertireoidismo; Hipotireoidismo

\section{Contributors}

I. M. Benseñor participated in the design, analysis and interpretation of data, write-up and revision of the article. A. C. Goulart participated in the data analysis, writeup and revision of the article. P. A. Lotufo participated in the article design, data interpretation and revision of the manuscript. P. R. Menezes and M. Scazufca participated in data interpretation, write-up and revision of the article.

\section{Acknowledgments}

To the São Paulo State Research Foundation (FAPESP) and the Wellcome Trust for financial support.

\section{References}

1. Sawin CT, Castelli WP, Hershman JM, McNamara P, Bacharach P. The aging thyroid. Thyroid deficiency in the Framingham Study. Arch Intern Med 1985; 145:1386-8

2. Bemben DA, Winn P, Hamm RM, Morgan L, Davis A, Barton E. Thyroid disease in the elderly. Part 1. Prevalence of undiagnosed hypothyroidism. J Fam Pract 1994; 38:577-82.

3. Sawin CT, Geller A, Wolf PA, Belanger AJ, Baker E, Bacharach $\mathrm{P}$, et al. Low serum thyrotropin concentrations as a risk factor for atrial fibrillation in older persons. N Engl J Med 1994; 331:1249-52.

4. Hak AE, Pols HA, Visser TJ, Drexhage HA, Hofman A, Witteman JC. Subclinical hypothyroidism is an independent risk factor for atherosclerosis and myocardial infarction in elderly women: the Rotterdam Study. Ann Intern Med 2000; 132:270-8.

5. Luboshitzky R, Aviv A, Herer P, Lavie L. Risk factors for cardiovascular disease in women with subclinical hypothyroidism. Thyroid 2002; 12:421-5.
6. Parle JV, Maisonneuve P, Sheppard MC, Boyle P, Franklin JA. Prediction of all-cause and cardiovascular mortality in elderly people from one low serum thyrotropin result: a 10-year cohort study. Lancet 2001; 358:861-5.

7. Clinical guideline, part 1. Screening for thyroid disease. American College of Physicians. Ann Intern Med 1998; 129:141-3.

8. Danese MD, Powe NR, Sawin CT, Ladenson PW. Screening for mild thyroid failure at the periodic health examination: a decision and cost-effectiveness analysis. JAMA 1996; 276:285-92.

9. Ladenson PW, Singer PA, Ain KB, Bagchi N, Bigos ST, Levy EG, et al. American Thyroid Association for detection of thyroid dysfunction. Arch Intern Med 2000; 160:1573-5.

10. Agency for Healthcare Research and Quality. Screening for thyroid disease http://www.ahrq. gov/clinic/uspstf/uspsthyr.htm (accessed on 20/ Dec/2007). 
11. Canadian Task Force on Preventive Health Care. Canadian Task Force on the periodic health examination. http://www.ctfphc.org/Abstracts_print able/Ch51abs.htm (accessed on 20/Dec/2007).

12. Bahemuka M, Hodkinson HM. Screening for hypothyroidism in elderly inpatients. Br Med J 1975; 2:601-3.

13. Scazufca M, Menezes PR, Vallada HP, Crepaldi AL, Pastor-Valero M, Coutinho LM, et al. High prevalence of dementia among older adults from poor socioeconomic backgrounds in São Paulo, Brazil. Int Psychogeriatr 2008; 20:394-405.

14. Scazufca M, Seabra CA. São Paulo portraits: ageing in a large metropolis. Int J Epidemiol 2008; 37:721-3.

15. Andersen-Ranberg K, Jeune B, Høier-Madsen M, Hegedüs L. Thyroid function, morphology and prevalence of thyroid disease in a populationbased study of Danish centenarians. J Am Geriatr Soc 1999; 47:1238-43.

16. Canaris GJ, Manowitz NR, Mayor G, Ridgway EC. The Colorado thyroid disease prevalence study. Arch Intern Med 2000; 160:526-34.

17. Gussekloo J, Exel R, Craen AJM, Meinders AE, Frölich M, Western RGJ. Thyroid status, disability and cognitive function, and survival in old age. JAMA 2004; 292:2591-9.
18. Anjum Q, Alam E, Rizvi R, Usman J, Shaikh S, Ahmed Y. Morbidity pattern and utilization of a primary health care center in a low socioeconomic area of Karachi. J Pak Med Assoc 2006; 56:13-6.

19. Koutis $\mathrm{AD}$, Isacsson $\mathrm{A}$, Lindholm LH, Lionis CD, Svenninger K, Fioretos M. Use of primary health in Spili, Crete, and in Dalby, Sweden. Scand J Prim Health Care 1991; 9:297-302.

20. Stoverinck MJ, Lagro-Janssen AL, Weel CV. Sex differences in health problems, diagnostic testing, and referral in primary care. J Fam Pract 1996; 43:567-76.

21. Aquino EM, Menezes GM, Amoedo MB. Gender and health in Brazil: considerations based on the National Household Sampling Survey. Rev Saúde Pública 1992; 26:195-202.

22. Hollowell JG, Staehling NW, Flanders D, Hannon H, Gunter EW, Spender CA, et al. Serum TSH, T4, and thyroid antibodies in the United States population (1988 to 1994): National Health and Nutrition Examination Survey (NHANES III). J Clin Endocrinol Metab 2002; 87:489-99.

Submitted on $02 /$ Dec/2009

Final version resubmitted on $05 / \mathrm{Jul} / 2010$

Approved on 11/Aug/2010 